\title{
Noisy Modernization? On the History and Historicization of Sound
}

Josephine Hoegaerts and Kaarina Kilpiö

HCM 7: 610-618

DOI: $10.18352 / \mathrm{hcm} .576$

\begin{abstract}
Sound 'does' things to places, to people and to time: it can affect change. This collection focuses specifically on the role sound has played as an agent of modernity. How were sound and music used as the material of modernization, how did they help create group identities, how were they mobilized in asserting power? In order to study this active quality of sound and music in the formation of the modern world, the contributors to this collection propose an interdisciplinary approach, including methods from sound studies and cultural musicology, and data from archives as well as record collections and catalogues.
\end{abstract}

Keywords: critical musicology, ethnomusicology, noise, recordings, silence, sound, sound studies, urbanization

Let us draw you a picture: Cambridge, I I November I 893. It is a cold day, and due to various fevers and colds an abysmally small number of people has shown up for the debate of the Union Society. In the absence of one of the speakers, a certain 'Mr. Binning' extemporizes on the subject of the admission of women and the lower classes to higher education. As usual, a reporter of the student paper Granta is present at the debate, and finds himself struggling with a very modern conundrum. Journalistic standards by the end of the nineteenth century demanded a precise, truthful rendition of the debate. However, the reporter noted, 
'it is impossible to reproduce Mr. Binning on paper. A phonograph is needed to catch the accent'. ${ }^{\text {. }}$

It is a problem familiar to most historians: sound (whether spoken or otherwise) needs mediation in order to survive the passage of time, and most technology to 'preserve' historical sounds are frustratingly mute. ${ }^{2}$ One could ask, then, whether sound, with its eerie qualities and its inability to keep its shape over time, even has a history. And if it does, how such a history can be written in the absence of documents that can truly represent its basic characteristics. (It is only from the late nineteenth century onwards that technology to reproduce sounds becomes available, and these of course come with their own methodological challenges). ${ }^{3}$ This special collection attempts to offer some answers to these questions. It focuses particularly on the ways in which the methodological strides that have been made by researchers in the fields of cultural musicology and sound studies can be mobilized by historians of modernity.

Our image of 'modernity', even if it is largely visual, is suffused with sounds. The clang of machinery, the hiss of the steam train, the frantic clacking of typing machines and the various noises of city life ... they easily enter our minds when we think of modernity and modernization. Moreover, in the last few decades, copious research in social and cultural history has shown how not only industrial sounds and music, but also sounds such as birdsong and silence reflected the changing circumstances caused by modernization, and how 'auditory' material can be mobilized effectively to analyze the history of modernity and narratives of modernization. ${ }^{4}$ The move towards this more visceral approach to history and sensations of the past is not necessarily new. Researchers working on the 'history of senses', for example, have studied the cultural importance and meanings of experiencing through touch, smell and hearing since the $1980 .{ }^{5}$ More recently, this analysis of 'experience' as historical has also turned historians' attention to cognitive processes and the ontological world that is open to human (and, in some cases, non or post-human) experience. ${ }^{6}$ Often in close connection to or in collaboration with histories of emotions, historians of experience are now mapping out sensorial skills and sensations of the past in new ways. Sound, we would argue, should play an important role in such considerations, especially since various researchers have recently pointed to the cultural skills and embodied practices that are involved in 
hearing, listening to and producing sound. ${ }^{7}$ In attending to what people of the past heard and how they gave and took meaning from what they heard, we learn to think about the past differently.

Sounds and music are not mere reflections of social and cultural realities, however, and in this collection we want to focus specifically on the role they played as an agent of modernity. How were sound and music used as the material of modernization, how did they help create group identities, how were they mobilized in asserting power? The contributors to this special collection have provided very different methodological approaches to these issues, and therefore have very different answers to offer. Moreover, the array of different vantage points from which they have chosen to 'listen out' for modernizing impulses and processes shows that auditory skills, sonic personae and sounding practices took shape in all kinds of places (from Belgian bureaucrats' offices to the recording studios of beguine in the French West Indies) and travelled widely to boot. They were given shape by a number of different historical actors (from professional musicians to construction workers) and could grow far beyond their size (in which a puny minute of silence could eventually culturally drown out metropolitan noise). Sound 'does' things to places, people and to time, and what it does and how it affects change matters to historians - particularly, perhaps, to those interested in processes of modernization.

In order to study this active quality of sound and music and their contribution to modernization, this special collection proposes an explicitly interdisciplinary approach. More concretely, we suggest that histories of sound as a driving force of modernization can (and should) lean on the methodologies and findings of sound studies and cultural musicology. Recent forays in the interdisciplinary field of sound studies have been, in the words of Jonathan Sterne, 'exploring the ways in which the history of sounds contributes to and develops from the maelstrom of modern life', ${ }^{8}$ focusing on processes such as industrialization, urbanization, medicalization and the rise of consumerism. In the last decade, the field of sound studies has grown steadily, resulting in a vast array of empirical and methodological contributions as well as a number of 'overviews' of the field including readers and handbooks for those who want to enter the field. ${ }^{9}$

Meanwhile, cultural musicologists' insistence on the social nature of music and its dependence on its cultural and political context draws 
music into the heart of socio-cultural understandings of modernity as well, as an active shaper of communities and the changes within them (supporting for example the rise of the nation state, but also protest movements). ${ }^{10}$ Understanding the swift changes in the everyday sonic environment has been a shared goal for cultural musicologists and historians of (sound) technology. The ever-regenerating roles of the auditory open a fresh approach to studying the modernizing processes in both these fields.

If one conclusion can be arrived at, it is perhaps that such a cross-disciplinary approach to sounds of the past remains a matter of historicization. Or in other words, that historians have an important contribution to make to the study of sound and its changing cultural meanings. As Sterne has pointed out in his influential book on The Audible Past, telling the story of sound, and of the sound of modernity in particular, largely depends on the ability to make the most of the 'paper trail' left by sound reproduction technologies, performances and practices. ${ }^{\text {II }}$ Counter-intuitively, perhaps, this puts familiarity with and knowledge of archival approaches to the past at the centre of any study of historical sounds. In an almost synesthetic move towards cross-disciplinarity, the historian's familiarly 'feverish' ${ }^{12}$ engagement with the tangible reality of the archive opens up possibilities to make sounds of the past 'present' again. Sound is, after all, felt as well as heard. ${ }^{13}$ And so the historian, who may be ill-equipped when it comes to musical ears or rhythmic physicality and have limited notation reading skills, can put her experience with dust and the archival void of past lives to good use when tracing back something that was alive so very briefly and yet resounds throughout history. ${ }^{14}$

This thematic contribution to the International Journal for History, Culture and Modernity includes articles from sound studies scholars, ethnomusicologists and historians of different stripes. Several writers represent more than one area of expertise.

The issue opens with two 'reviews', from the perspective (and reflecting the opinions, assessments and hopes) of two experts who define their field in very different ways. Ethnomusicologist and sound archive expert Pekka Gronow focuses on the history and historiography of recorded sound. Delving into his experience as both a participant in and observer of this history, Gronow discusses the omissions and gaps in knowledge as well as the input of 'professional' and 'amateur' 
historians. This balancing act between professionalization and enthusiasm will be familiar to historians in other fields, but takes a particular shape in a world in which the act of collecting also provides one with very particular auditory (as well as technical) skills. Gronow's look toward the future is very much one of expansion: towards different cultural contexts, toward 'other' genres of music and toward new ways of recording, archiving and replaying. Cultural historian of sound and the senses Daniel Morat, in his reflection on 'The Sound of a New Era' turns resolutely towards the historically changing experience of sound. In doing so, he offers a reappraisal of classic histories of sound (such as Corbin's and Thompson's) in order to come to new understandings of the 'transformation' of auditory experience in the context of the rapid modernization of urban spaces in the long fin de siècle. Seeing these 'transformations' as a central concern in understanding and analyzing sounds of the past, Morat shows, also equips us with new ways to think about sounds and modes of hearing in the present, as 'the outcome of a historical process'.

Two research articles, representing the meeting of historical research with cultural musicology on the one hand, and with sound studies on the other, show how the advances in both these fields can be fruitfully used to come to truly new understandings of history. Rachel Beckles Willson's 'Hearing Global Modernity' offers a new way to think about trans and international mobility, processes of (de)colonization and issues of modern 'globalization' by focusing on the travels and changing audibility of the oud, a lute-like instrument of the MiddleEast. Approaching the instrument not only as an object (one that could be taken out of its original contexts and put in museums, for example) but also as a vehicle for cultural and sonic practice (one that can again be listened to, and can find audiences across the world) Beckles Willson shows how attending to music and musical instruments can allow us to make room for the tragedies of (cultural) erasure that have accompanied the history of colonialism and globalization. Karsten Lichau's contribution, 'Soundproof Silences' draws our attention to another powerful aural means of erasure: that of active, politically mobilized and meaningful silence. Approaching silence as a focal point, rather than a lacuna, in sound studies and sound history, leads Lichau to develop an understanding of silence as Klanghandeln. In applying this concept of silence as Klanghandeln to the case of the minute silence 
and its political staging, he also shows how paying close attention to the soundscape of such politicized moments can help us to historicize the interplay between politics, emotion and modern 'public' life. In scrutinizing these performances of silence, the dichotomy between 'performer' and 'audience' on the political stage is broken, and all (silent) historical actors become political 'performers' in their own right.

These empirical research articles are followed by a substantial 'discussion' on the interplay between sound and the modern city. Nimrod Ben Zeev, Annelies Jacobs and Jens van de Maele share a focus on modernization through case studies in environments of urban and working life. They deal with issues of privacy and security as well as different positions of actors within the environments and sources they study. Although the contexts of their research (the soundscapes of turn-ofthe-twentieth-century Amsterdam, the early twentieth-century Belgian office and construction sites in modern Palestine) are widely different, all authors issue a strong invitation to think about sound history as a way towards questioning the kind of daily practices of urban life that are often taken for granted in both the past and the present. The commentary by Meri Kytö, in drawing these case studies together, repeats such an invitation to critically question the 'natural' presence of sound in our, and in historical actors', daily lives.

To summarize, the scholars involved in writing this issue offer a wide range of suggestions on how to tackle the problem of the "muteness' of historical sources. The lack of sound recording lamented by the Granta reporter in I 893, and the physical degradation of existing historical recordings, continually pose challenges to approaching history from sonic angles. These challenges are not insurmountable, however, and in daring to face them essential understanding is also gained on how to document and administer the sonic aspects of recent history and today.

\section{Notes}

I The anecdote plays its part in a larger research project on political speech, in the context of which work for this special collection was undertaken (CALLIOPE, ERC StG 20I7). 
2 As Jonathan Rée has pointed out, recordings never 'preserve' sounds, they merely provide (incomplete) copies. Jonathan Rée, I See a Voice. Deafness, Language and the Senses (New York, I999), 9.

3 One of them is the 'period ear': the way in which we hear and assign meaning to sound not only depends on the sounds produced (i.e. what we physically can perceive) but also the way in which we have learned to listen and understand. See e.g. Gina Bloom, Voice in Motion: Staging Gender, Shaping Sound in Early Modern England (Philadelphia, 2007). Another challenge is the sheer technicality of recording as a practice and the difficulty of replaying older records that may have become severely damaged and distorted over time. This is most obviously true for wax cylinders, perhaps, but also applies to much newer digital recording technology which can become obsolete very rapidly. See e.g. Jonathan Sterne, $M P_{3}$, the Meaning of a Format (Durham, 2012).

4 See e.g. Emily Thompson, The Soundscape of Modernity: Architectural Acoustics and the Culture of Listening in America, I90O-I933 (Cambridge, MA, 2002); Carolyn Birdsall, Nazi Soundscapes: Sound, Technology and Urban Space in Germany, I933-1945 (Amsterdam, 201 2); Pieter Verstraete and Josephine Hoegaerts, Stilte. Essays over cultuur, macht en verandering (Leuven, 20 I5); Jouri Bruyninckx, Listening in the Field. Recording and the Science of Birdsong (Cambridge, MA, 2018).

5 E.g. Alain Corbin, Le Miasme et la Jonquille. L'odorat et l'imaginaire social, XVIII ${ }^{e}$-XIX ${ }^{e}$ siècles (Paris, I986); idem, Les Cloches de la terre. Paysage sonore et culture sensible dans les campagnes au XIXe siècle (Paris, 2000); Mark Smith, Sensory History (London, 2007); Paul Stoller, Sensuous Scholarship (Philadelphia,, I997); William Tullett, Smell in Eighteenth Century England: A Social Sense (Oxford, 2019); Herman Roodenburg (ed.) A Cultural History of the Senses in the Renaissance (London, 2016).

6 E.g. Rob Boddice, A History of Feelings (London, 20 I9); Rob Boddice and Mark Smith (eds) Emotion, Sense, Experience (Cambridge, 2020); Ruth Leys, The Ascent of Affect. Genealogy and Critique (Chicago, 2017).

7 E.g. Holger Schulze, The Sonic Persona: An Anthropology of Sound (London, 20I8); Mara Mills, 'Optophones and Musical Print', The Sounding Out! Blog (5 January 20I5); Nina Eidsheim, Sensing Sound. Singing and Listening as Vibrational Practice (Durham, 20 I5).

8 Jonathan Sterne, The Audible Past. Cultural Origins of Sound Reproduction (Durham, 2003), 9. 
9 Karin Bijsterveld and Trevor Pinch, Oxford Handbook of Sound Studies (Oxford, 20I I); Jonathan Sterne, The Sound Studies Reader (New York, 20 I2); Joy Damousi and Paula Hamilton (eds), A Cultural History of Sound, Memory, and the Senses (New York, 20 I7); Karin Bijsterveld, Sonic Skills: Listening for Knowledge in Science, Medicine and Engineering (I920sPresent) (New York, 20I9); Holger Schulze (ed.), Bloomsbury handbook of the anthropology of sound (London, 2020); Daniel Morat and Jansjakob Ziemer, Handbuch Sound. Geschichte - Begriffe - Ansätze (Stuttgart, 20I8); Michael Bull (ed.) The Routledge Companion to Sound Studies (New York, 2018).

Io E.g. Philip Bohlman, Focus: Music, Nationalism, and the Making of the New Europe (Santa Barbara, 2010).

I I Sterne, The Audible Past, 7.

I 2 Carolyn Steedman, Dust (Manchester, 200I), I7.

I3 Eidsheim, Sensing Sound.

I4 One of the main threads in anthropological as well as philosophical reflections on sound is its 'eerie' quality: it disappears immediately. This is true for both sounds perceived by humans of the past (i.e. the practices of listening and hearing) as for sounds produced (the physical but ultimately still disembodying act of speaking or singing). See e.g. Steven Connor, Dumbstruck. A Cultural History of Ventriloquism (Oxford, 200I); Arlette Farge, Essai pour une histoire des voix au dix-huitième siècle, Paris, 2009; Peter Szendy, Ecoute. Une histoire de nos oreilles (Paris, 200I).

\section{About the Authors}

Josephine Hoegaerts is Associate Professor of European Studies at the University of Helsinki. Her research focuses on the history of the human voice, and the different practices and meanings attached to speech and song. She leads the project 'CALLIOPE: Vocal Articulations of Identity and Empire'. Recently, she authored 'Women's Voices in Educational Manuals. The Gendered Sounds of Speech Therapy, Song and Education in Europe, c.I830-I900', Women's History Review (2019). She has also co-edited several journal issues on sound, music and silence: on Music, Gender and Inequality (Tijdschrift voor Genderstudies, 20I9, with Pauwke Berkers and Inger Plaisier), on Educational Soundscapes (Paedagogica Historica, 20I7, with Pieter Verstraete) and Silence and 
Diversity (DiGest, 2016); and a volume on silence (Stilte: Essays over macht, cultuur en verandering, 20I5).

E-mail: Josephine.hoegaerts@helsinki.fi

Kaarina Kilpiö is University Lecturer at Sibelius Academy, University of the Arts, Helsinki. She currently works as research fellow at Åbo Akademi University and University of Eastern Finland. Her research interests cover different historical uses of music and sound technologies. In addition to numerous articles about advertising and propaganda music, background music, the design of soundscapes in public spaces and practices of music users, she has published on Finnish advertising film music from the I950s to the I970s (2005), and a book on cassette culture in Finland (2015). She has also co-edited several volumes on music and soundscape, including Kuultava menneisyys (2005), an anthology of Finnish soundscape history, and Music History and Cosmopolitanism (2019).

E-mail: kaarina.kilpio@uniarts.fi 